International Journal of Engineering \& Technology, $7(4.7)(2018) 330-334$
International Journal of Engineering \& Technology
SPC
Website: www.sciencepubco.com/index.php/IJET
Research paper

\title{
Various Impregnation Methods Used for the Surface Modification of the Adsorbent: A Review
}

\author{
C. R. Girish \\ Chemical Engineering Department, Manipal Institute of Technology, Manipal Academy of Higher Education, Manipal, Karnataka, India
}

\begin{abstract}
The water contamination is an important crisis which is to be addressed in the recent time. The pollutants present in wastewater are treated by adsorption using activated carbon, which is considered as one of the effective method. The adsorbent has to be modified to improve the adsorption capacity and the surface properties. Various methods such as physical, chemical treatment, impregnation and functionalization techniques are available. Impregnation is one of the effective method carried out for surface modification and to increase the adsorption capacity. Therefore, current study investigates the different impregnation methods used for the surface modification of the adsorbent. It also reviews the various precursors used for adsorbent preparation, the impregnating agent, the operating conditions and the adsorption capacity of the adsorbent.
\end{abstract}

Keywords: impregnation, porous material, modification, adsorbent, surface property

\section{Introduction}

In the recent time, water pollution is becoming an issue of concern all over the world. Because of the overgrowing population there is a requirement to produce more resources to meet the daily needs of the society. Therefore these activities results in producing and releasing the pollutants into the environment [1]. The chemical industries namely pulp and paper, electroplating, petroleum refineries, fertilizer industries and various manufacturing industries releases wastewater containing different pollutants [2]. Therefore it is required to treat these pollutants before it is released into the environment. Various treatment methods such as chemical precipitation, membrane separation, ultrafiltration, pervaporation, adsorption using activated carbon and advanced oxidation methods can be used to treat the wastewater containing contaminants [3]. Adsorption using porous adsorbent is an efficient process which removes the toxic pollutants from wastewater [4]. It also requires low cost and less energy in comparison with other treatment methods and also the used adsorbent can be regenerated [5]. The activated carbon which is having high affinity to most of the contaminants and possessing large surface area makes it favorable for the process [6].

\section{Different Types of Surface Modification Methods}

Various treatment methods are used for modifying the surface of the adsorbent so that the affinity of the solute towards the adsorbent can be improved and the adsorption capacity can be increased. The prominent methods used are chemical treatment and physical treatment methods. Various chemicals such as acids, bases, surfactants, oxidizing agents, metal salts are used for the above processes $[7,8,9]$. The modification of the surface can be done by metal impregnation, chemical grafting and functionalization techniques $[10,11,12]$. In chemical grafting method, the chemical species are fixed onto the solid surface by covalent bonds formed between the surface and the species. This method has advantages that adsorption kinetics is faster, exhibit stable properties during regenerating of the adsorbent. On the other hand they have lower adsorption capacity because of the lower surface area. In the impregnation method the chemical species are blended inside the pores physically to modify the surface. The preparation technique is simple and it shows high adsorption capacity. The pore volume and pore diameter was enhanced by regulating the solid structure [12].The impregnation methods can be dry impregnation [13] or wet impregnation method $[14,15]$ depending on the way by which the solvent is added onto the surface of the adsorbent. In dry impregnation method the fixed quantity of solvent is added in such a way that the pores of the adsorbent are just filled, whereas in wet impregnation solvent more than the volume of the pores are added and after filling the pores, the excess chemical is dried and the loading of the chemical species can be controlled [16].

The impregnation on the solid surface was performed by using anionic surfactants which will increase the active sites [8]. It was reported that by impregnating the surface with metal salts results in the formation of oxide film on the surface. This modified surface has the capability to decrease the regeneration temperature and increase the life time of the adsorbent [17]. The impregnated adsorbent has the advantage that it is stable and has promising regeneration capacity in comparison with normal adsorbents [10]. The mesoporous materials have large surface area, better porous arrangement, thus these porous materials are produced by incipient- wetness impregnation technique [18]. The impregnation method is generally carried out in two steps. In the first step a layer of material is applied in order to change the surface and texture of the adsorbent. The second step comprises of depositing the material which is used for thermal activation [19]. The second step also facilitates in retaining the chemical species inside the inter particle space [20]. 


\section{The Importance of Porous Materials}

Porous materials have disadvantages that they are non-selective and inefficient to some of the pollutants. The preparation of adsorbent from expensive materials is also considered to be a problem of concern. Thus the adsorbents can be produced from low cost materials. The idea of preparing adsorbent from waste material also solves the problem of waste disposal [21, 22]. The adsorbent prepared from carbonaceous materials have disadvantages that it is hygroscopic in nature, pores inside may be blocked and may lead to combustion at higher temperature [23]. Because of dissimilar chemical characteristics between the metal species and solid surface, the attractive forces for the adsorption will be inhibited [8]. Thus the activated carbon without any modification have less adsorption capacity, therefore surface modification is required to improve the properties [17, 24, 25].

The modified adsorbent can have higher capacity because of chemisorption of pollutants onto the adsorbent surface [26]. The surface chemistry of the materials changes because of the impregnation $[27,28,29]$. The modification of the adsorbent reduces the amount of the adsorbent required for the process [30]. Through the process of impregnation the carbonaceous materials which are unstable may be provided support [23]. The impregnated materials have the advantages that regeneration is not necessary during oxidation [31]. The stability of the impregnated materials increases and provides higher surface area necessary for removing the pollutants [32].
It was discussed that by treating the carbon with amine improves the affinity of the adsorbent towards polar molecules where stronger forces than the van der Waals forces are produced [33]. The modification was done by using surfactants where the surfactant molecule layer gets arranged on the solid surface by a mechanism called self-associated clusters [34]. It was reported that some of the fine materials like iron and iron oxide when used as adsorbents becomes difficult to handle in the process. Therefore impregnation of these materials are required for preventing the loss of material and for implementing to scale- up of the process [35]. The porous materials were used to pre-concentrate the hazardous pollutants in the wastewater treatment and can be used for most of the separation processes [36]. It was studied that porous materials have pore sizes which can be adjusted and stable chemical structure which is a necessary requirement for the adsorption [37]. These porous materials are applied in the field of catalysis, purification techniques and separation processes [23]. Therefore an effort has been made to review the various modifications done on the surface of the adsorbent material to improve the properties and adsorption capacity.

The summarization of all the parameters such as various precursors, impregnating agent used for adsorbent preparation, the pollutant removed, the operating conditions and the adsorption capacity are listed in Table 1. The interesting findings from the recent literature like the advantages of different methods, the impregnating agent, and the possible reasons for the adsorption process are discussed below.

Table 1: The summarization of the parameters such as precursors used, impregnating agent, experimental conditions for surface modification and the adsorption capacity

\begin{tabular}{|c|c|c|c|c|c|c|}
\hline $\begin{array}{l}\text { Sl. } \\
\text { No. }\end{array}$ & $\begin{array}{l}\text { Precursor for } \\
\text { adsorbent }\end{array}$ & $\begin{array}{l}\text { Chemical used for impregna- } \\
\text { tion }\end{array}$ & Pollutant & Experimental conditions & $\begin{array}{l}\text { Adsorption } \\
\text { capacity }\end{array}$ & Ref. \\
\hline 1 & Saw dust & $\begin{array}{l}\text { Aluminium chloride, manganese } \\
\text { chloride, potassium permanga- } \\
\text { nate }\end{array}$ & Arsenic & $\begin{array}{l}0.1 \text { and } 0.4 \mathrm{mM}, 1 \mathrm{~g} / \mathrm{L}, 24 \mathrm{~h}, 25^{\circ} \mathrm{C}, \\
\text { pH } 6\end{array}$ & 17.76 & {$[38]$} \\
\hline 2 & $\begin{array}{l}\text { Sugarcane } \\
\text { bagasse }\end{array}$ & Ferric chloride & chromium & $\begin{array}{l}25-130 \mathrm{mg} / \mathrm{L}, 0.1-0.6 \mathrm{~g} / 50 \mathrm{~mL}, 20- \\
40^{\circ} \mathrm{C}, \mathrm{pH} 1-10,200 \mathrm{rpm}, 72 \mathrm{~h}\end{array}$ & 13.72 & [39] \\
\hline 3 & $\begin{array}{l}\text { Granular acti- } \\
\text { vated carbon }\end{array}$ & Ferric chloride & copper & $\begin{array}{l}1 \times 10^{-5}, 1 \times 10^{-4} \mathrm{M}, 0.2 \\
\mathrm{~g} / 100 \mathrm{~mL}, 25^{\circ} \mathrm{C}, \mathrm{pH} 2-9,24 \mathrm{~h}\end{array}$ & $99 \%$ removal & [40] \\
\hline \multirow[t]{2}{*}{4} & Collagen fiber & zirconium & Vanadium & $\begin{array}{l}2-6 \mathrm{mmol} / \mathrm{L}, 0.1 \mathrm{~g} / 100 \mathrm{~mL}, \mathrm{pH} 5 \text {, } \\
303-323 \mathrm{~K}, 24 \mathrm{~h}\end{array}$ & $3.18 \mathrm{mmol} / \mathrm{g}$ & \\
\hline & & & chromium & $\begin{array}{l}0.4-2 \mathrm{mmol} / \mathrm{L}, 0.1 \mathrm{~g} / 100 \mathrm{~mL}, \mathrm{pH} 7, \\
303-323 \mathrm{~K}, 24 \mathrm{~h}\end{array}$ & $0.691 \mathrm{mmol} / \mathrm{g}$ & [41] \\
\hline 5 & chitosan & cerium & arsenic & $\begin{array}{l}0-60 \mathrm{mg} / \mathrm{L}, 20 \mathrm{mg} / 100 \mathrm{~mL} \text { solution, } \\
\mathrm{pH} 2-11,150 \mathrm{rpm}\end{array}$ & 57.5 & [42] \\
\hline \multirow[t]{3}{*}{6} & Sugar beet pulp & Iron & arsenic & $100,500,1000 \mu \mathrm{g} / \mathrm{L}, 0.05 \mathrm{~g} / 100 \mathrm{~mL}$ & 2.936 & \\
\hline & & Hydrogen peroxide, iron & & & 3.246 & \\
\hline & & Manganese dioxide, iron & & & 16.844 & [43] \\
\hline 7 & $\begin{array}{l}\text { Amberlite } \\
\text { XAD-8 }\end{array}$ & $\begin{array}{l}\text { Di-(2-ethylhexyl) Phosphoric } \\
\text { Acid }\end{array}$ & chromium & $\begin{array}{l}10 \mathrm{mg} / \mathrm{L}, 0.1 \mathrm{~g} / 25 \mathrm{~mL}, \mathrm{pH} 1-5.5,298 \\
\mathrm{~K}, 150 \mathrm{rpm}, 2 \mathrm{~h}\end{array}$ & 5.64 & [44] \\
\hline 8 & Bamboo & Nickel & lead & $\begin{array}{l}50 \mathrm{mg} / \mathrm{L}, 1 \mathrm{~g} / \mathrm{L}, 288-308 \mathrm{~K}, \mathrm{pH} 1-7, \\
24 \mathrm{~h}\end{array}$ & 142.7 & {$[45]$} \\
\hline 9 & $\begin{array}{l}\text { Activated car- } \\
\text { bon }\end{array}$ & Humic acid & copper & $\begin{array}{l}6.1 \mathrm{mg} / \mathrm{L}, 20 \mathrm{mg} / 40 \mathrm{~mL} \text { of solution, } \\
\mathrm{pH} 2-6,120 \mathrm{rpm}, 20^{\circ} \mathrm{C}, 2 \mathrm{~h}\end{array}$ & 5.95 & [46] \\
\hline 10 & $\begin{array}{l}\text { SBA } 15 \text { meso- } \\
\text { porous materi- } \\
\text { als }\end{array}$ & $\mathrm{Al}_{2} \mathrm{O}_{3}$ and $\mathrm{Fe}_{2} \mathrm{O}_{3}$ & arsenic & $\begin{array}{l}1-50 \mathrm{mg} / \mathrm{L}, 0.5 \mathrm{~g} / \mathrm{L}, \mathrm{pH} 6.5,25^{\circ} \mathrm{C}, 200 \\
\mathrm{rpm}, 24 \mathrm{~h}\end{array}$ & 43.5 & [47] \\
\hline 11 & $\begin{array}{l}\text { Peganum har- } \\
\text { mala seeds }\end{array}$ & $\mathrm{ZnO}$ & chromium & $\begin{array}{l}10-100 \mathrm{mg} / \mathrm{L}, 1-10 \mathrm{~g} / \mathrm{L} \text { solution, } 10- \\
50^{\circ} \mathrm{C}, 0-300 \mathrm{rpm}, \mathrm{pH} 2-8,10-80 \mathrm{~min}\end{array}$ & 68.49 & [48] \\
\hline 12 & Silica beads & $\begin{array}{l}\text { 2-hydroxy-5- } \\
\text { nonylacetophenoneoxime, } \gamma \text { - } \\
\text { aminopropyltriethoxysilane }\end{array}$ & copper & $\begin{array}{l}5 \mathrm{mmol} / \mathrm{dm}^{3}, 0.1-5 \mathrm{~g} / 25 \mathrm{~cm}^{3} \text { solution, } \\
\mathrm{pH} 4,48 \mathrm{~h}\end{array}$ & $0.0806 \mathrm{mmol} / \mathrm{g}$ & [49] \\
\hline 13 & Polyaniline & Cerium oxide & chromium & $\begin{array}{l}1-49 \mathrm{mg} / \mathrm{L}, 0.1-1 \mathrm{~g} / 100 \mathrm{~mL} \text { solution, } \\
\mathrm{pH} 2-10,20-100 \mathrm{~min}, 30-90^{\circ} \mathrm{C}\end{array}$ & 357 & [50] \\
\hline \multirow[t]{4}{*}{14} & Rice husk ash & $\mathrm{AlCl}_{3}, \mathrm{FeCl}_{3}$, sodium carbonate & Lead & $\begin{array}{l}1-10 \mathrm{~min}, \mathrm{pH} 6-9,1-100 \mathrm{mg} / \mathrm{L} \text { solu- } \\
\text { tion, } 27^{\circ} \mathrm{C}, 10 \mathrm{mg} / \mathrm{L} \text { conc }\end{array}$ & 416 & \\
\hline & & & Iron & $\begin{array}{l}1-10 \mathrm{~min}, \mathrm{pH} 6-9,1-70 \mathrm{mg} / \mathrm{L} \text { solu- } \\
\text { tion, } 27^{\circ} \mathrm{C}, 4 \mathrm{mg} / \mathrm{L} \text { conc }\end{array}$ & 222 & \\
\hline & & & Manganese & $\begin{array}{l}1-10 \mathrm{~min}, \mathrm{pH} 6-9,1-70 \mathrm{mg} / \mathrm{L} \text { solu- } \\
\text { tion, } 27^{\circ} \mathrm{C}, 3 \mathrm{mg} / \mathrm{L}\end{array}$ & 158 & \\
\hline & & & arsenic & $\begin{array}{l}1-10 \mathrm{~min}, \mathrm{pH} 6-9,1-28 \mathrm{mg} / \mathrm{L} \text { solu- } \\
\text { tion, } 27^{\circ} \mathrm{C}, 1.5 \mathrm{mg} / \mathrm{L}\end{array}$ & 146 & [51] \\
\hline 15 & Volcanic raw & magnesium oxide & cadmium & $5-40 \mathrm{mg} / \mathrm{L}, 2-10 \mathrm{~g} / \mathrm{L}$ solution, $\mathrm{pH} 3-$ & 31.25 & [52] \\
\hline
\end{tabular}




\begin{tabular}{|c|c|c|c|c|c|c|}
\hline & tuff soil & & & $11,0-360 \mathrm{~min}, 20^{\circ} \mathrm{C}$ & & \\
\hline \multirow[t]{2}{*}{16} & $\begin{array}{l}\text { Polysulfone } \\
\text { membranes }\end{array}$ & Zeolite particles & Lead & $500 \mathrm{mg} / \mathrm{L}, 25^{\circ} \mathrm{C}, \mathrm{pH} 6,1$ bar & $91 \%$ recovery & \\
\hline & & & nickel & & $42 \%$ recovery & [53] \\
\hline \multirow[t]{2}{*}{17} & Saw dust & Iron doped amino group & Arsenic (III) & $\begin{array}{l}1-50 \mathrm{mg} / \mathrm{L}, 0.1 \mathrm{~g} / 100 \mathrm{~mL} \text { solution, } \\
\mathrm{pH} 3-9,24 \mathrm{~h}, 150 \mathrm{rpm}\end{array}$ & 10.1 & \\
\hline & & & Arsenic (V) & & 43.7 & [54] \\
\hline \multirow[t]{2}{*}{18} & chitosan & $\mathrm{Fe}_{3} \mathrm{O}_{4}$ nanoparticles & Arsenic(III) & $\begin{array}{l}0.2-50 \mathrm{mg} / \mathrm{L}, 0.05 \mathrm{~g} / 50 \mathrm{~mL} \text { solution, } \\
\mathrm{pH} 6.8,140 \mathrm{rpm}\end{array}$ & 35.3 & \\
\hline & & & $\operatorname{Arsenic}(\mathrm{V})$ & & 35.7 & [55] \\
\hline 19 & coal & $\mathrm{K}_{2} \mathrm{~S}$ powder & mercury & $\begin{array}{l}24 \mathrm{mmol} / \mathrm{L}, 1 \mathrm{~g} / 100 \mathrm{~mL} \text { solution, } 25- \\
45^{\circ} \mathrm{C}, 120 \text { oscillations } / \mathrm{min}, 72 \mathrm{~h}\end{array}$ & $1.24 \mathrm{mmol} / \mathrm{g}$ & {$[56]$} \\
\hline 20 & Tea waste & $\mathrm{Fe}_{3} \mathrm{O}_{4}$ & nickel & $\begin{array}{l}50-100 \mathrm{mg} / \mathrm{L}, 0.4-0.6 \mathrm{~g} / \mathrm{in} 50 \mathrm{~mL} \\
\text { solution, 303-323K, } 100 \mathrm{rpm}, \mathrm{pH} 4\end{array}$ & 38.3 & [57] \\
\hline 21 & $\begin{array}{l}\text { Activated car- } \\
\text { bon }\end{array}$ & iron hydroxide & arsenic & $\begin{array}{l}300 \mathrm{~g} / \mathrm{L}, \mathrm{pH} 7,25^{\circ} \mathrm{C}, 15 \mathrm{mg} / 20 \mathrm{~mL} \\
\text { solution, }\end{array}$ & 0.847 & [58] \\
\hline 22 & Fly ash & Aluminium sluphate & phenol & $\begin{array}{l}200 \mathrm{mg} / \mathrm{L}, 5-25 \mathrm{~g} / \mathrm{L} \text { solution, } 3-15 \mathrm{~h} \text {, } \\
\mathrm{pH} 2-10,25-45^{\circ} \mathrm{C}\end{array}$ & 12.67 & [59] \\
\hline 23 & & & cadmium & & & {$[60]$} \\
\hline 24 & Chestnut shell & $\mathrm{FeCl}_{3}, \mathrm{FeCl}_{2}$ & arsenic & $\begin{array}{l}0.2-50 \mathrm{mg} / \mathrm{L}, 20 \mathrm{mg} / 50 \mathrm{~mL} \text { solution, } \\
298 \mathrm{~K}, \mathrm{pH} 2-11,24 \mathrm{~h}\end{array}$ & 45.80 & {$[61]$} \\
\hline \multirow[t]{2}{*}{25} & Rice straw char & $\mathrm{FeCl}_{3}$ & Arsenate & $\begin{array}{l}25-200 \mathrm{mg} / \mathrm{L}, 10 \mathrm{~g} / \mathrm{L} \text { solution, } 48 \mathrm{~h}, \\
150 \mathrm{rpm}, 25^{\circ} \mathrm{C}\end{array}$ & 9.70 & \\
\hline & & & cadmium & & 9.75 & {$[62]$} \\
\hline 26 & Corn straw & $\mathrm{FeCl}_{3}$ & arsenic & $\begin{array}{l}0.25-100 \mathrm{mg} / \mathrm{L}, 0.1 \mathrm{~g} / 20 \mathrm{~mL} \text { solution, } \\
80^{\circ} \mathrm{C}, 48 \mathrm{~h}\end{array}$ & 6.80 & [63] \\
\hline \multirow[t]{2}{*}{27} & $\begin{array}{l}\text { Powdered acti- } \\
\text { vated carbon }\end{array}$ & $\mathrm{Fe}_{3} \mathrm{O}_{4}$ & Lead & $\begin{array}{l}50-300 \mathrm{mg} / \mathrm{L}, 0.5-2 \mathrm{~g} / \mathrm{L} \text { solution, } \mathrm{pH} \\
2-10,300 \mathrm{~min}, 20-50^{\circ} \mathrm{C}\end{array}$ & 99.80 & \\
\hline & & & aniline & & 206.6 & [64] \\
\hline 28 & silica and lime & Potassium dihydrogen phosphate & cadmium & $\begin{array}{l}10-60 \mathrm{mg} / \mathrm{L}, 0.3 \mathrm{~g} / \mathrm{L} \text { solution, } 130 \\
\mathrm{r} / \mathrm{min}, \mathrm{pH} 5,10 \mathrm{~h}, 25^{\circ} \mathrm{C}\end{array}$ & 236.41 & [65] \\
\hline 29 & Graphene oxide & Trioctylamine & chromium & $\begin{array}{l}100 \mathrm{mg} / \mathrm{L}, 0.2 \mathrm{~g} / 50 \mathrm{~mL} \text { solution, } \mathrm{pH} \\
2.5\end{array}$ & 232.55 & [66] \\
\hline 30 & & & $\operatorname{Arsenic}(\mathrm{V})$ & & 55.1 & [67] \\
\hline 31 & alginate & zirconium oxide & chromium & $\begin{array}{l}10-500 \mathrm{mg} / \mathrm{L}, 0.05 \mathrm{~g} / 20 \mathrm{~mL} \text { solution, } \\
25^{\circ} \mathrm{C}, 150 \mathrm{rpm}\end{array}$ & 12.584 & [68] \\
\hline \multirow[t]{2}{*}{32} & Peanut shell & manganese oxide nanoparticles & Lead & $\begin{array}{l}3-53 \mathrm{mg} / \mathrm{L}, 0.2 \mathrm{~g} / \mathrm{L} \text { solution, } \mathrm{pH} 6 \text {, } \\
298 \mathrm{~K}\end{array}$ & 67.9 & \\
\hline & & & cadmium & $\begin{array}{l}3-33 \mathrm{mg} / \mathrm{L}, 0.2 \mathrm{~g} / \mathrm{L} \text { solution, } \mathrm{pH} 6 \text {, } \\
298 \mathrm{~K}\end{array}$ & 22.3 & [69] \\
\hline \multirow[t]{3}{*}{33} & Wheat straw & Bismuth oxide & Arsenic & $\begin{array}{l}5-200 \mathrm{mg} / \mathrm{L}, 0.01-1 \mathrm{~g} / 50 \mathrm{~mL} \text { solu- } \\
\text { tion, } 25^{\circ} \mathrm{C}, 150 \mathrm{rpm}, 24 \mathrm{~h}\end{array}$ & 0.273 & \\
\hline & & & Phosphorus & $60-1800 \mathrm{mg} / \mathrm{L}$ & 1.48 & \\
\hline & & & chromium & $5-200 \mathrm{mg} / \mathrm{L}$ & 12.23 & [70] \\
\hline
\end{tabular}

The adsorption of arsenic from aqueous solution using sawdust impregnated with aluminium oxide was studied by Wu et al. 2017. It was investigated that the functional group of oxygen present in aluminium oxides were mainly responsible for adsorption of the pollutant and it was because of surface complexation [38].

Yang et al. explored the feasibility of the activated carbon impregnated with iron used for removing copper from wastewater. The adsorbent exhibits a stronger acid proof property which is beneficial in treating wastewater [40].

The adsorption of vanadium and chromium on collagen fiber impregnated with zirconium was studied to be through ion exchange. The single charged vanadium species and the double charged chromium species were found to adsorb on the surface of the zirconium and thus it favours adsorption process [41].

Zhang et al. addressed the removal of arsenic from water with the help of cerium impregnated chitosan adsorbent. It was investigated that monodentate and bidentate complexes formed between arsenite and hydroxyl groups and also the partial oxidation of $\mathrm{As}(\mathrm{III})$ to $\mathrm{As}(\mathrm{V})$ were mainly responsible for the adsorption process [42].

Activated carbon loaded with iron were employed as adsorbent for removing arsenic from wastewater by Lodeiro et al. The results showed that the adsorption was because of the surface iron content and the strong acidic groups on the adsorbent surface [43].

Bamboo charcoal impregnated with nickel was used as a potential adsorbent for the removal of lead. The authors justified that be- cause of modification, the nickel modified adsorbent had better porosity and surface area compared to the untreated adsorbent. This was beneficial for the adsorption of the pollutant [45].

The capability of humic acid loaded activated carbon was tested for the removal of copper by Liu et al. It was understood that some functional groups are formed on the adsorbent surface that provides excess active sites required for the adsorption of pollutant. The adsorption performance of the adsorbent was almost the same in the wastewater and in the pure water showing the ability of the adsorbent [46].

In the adsorption of chromium using cerium oxide modified adsorbent it was observed that formation of electrostatic attractive forces and the complexation between the negatively charges chromium species and the positive charge $(\mathrm{NH}+)$ on the adsorbent surface were responsible for the adsorption [50].

The potential of rice husk ash treated with iron and aluminium was used as adsorbent for the removal of lead, iron, manganese and arsenic from wastewater. Using rice husk ash addresses the issue of depending on the low cost by product materials which are treated as waste materials [51].

The removal of lead and nickel from aqueous solution using polysulfone membranes loaded zeolite particles was explored by $\mathrm{Yu}-$ rekli. Various possible mechanisms were explained for the removal of metal ions. They are convective flow of the metal ions from the bulk solution to the membrane interface, diffusional flow of 
the ions from the membrane to the inside of the pores and the ion exchange inside the membrane framework [53].

The arsenic adsorption from wastewater chitosan beads impregnated with magnetic particles were studied by Wang et al. The magnetic adsorbent has the feature that it can be separated from the wastewater by applying external magnetic field. It was also found that the hydroxyl groups present on the solid surface were enhancing the adsorption [55]

In the work reported by Panneerselvam et al. on the adsorption of nickel onto tea waste, impregnation was carried out by using magnetic nanoparticles. The adsorption happening was mainly due to the ion exchange process. The authors inferred that hydrogen ion groups of the adsorbent gets attached to metal ions through electrostatic attraction [57].

The impregnated adsorbent was observed to be having more oxygen containing functional groups and having larger surface area Also because of increase in the $\mathrm{OH}$ and $\mathrm{COOH}$ groups in the modified adsorbent there was a strong affinity between the adsorbent and the pollutant and thus the adsorption capacity increased [60]. The adsorption of arsenic using magnetic gelatin modified biochar was investigated by Zhou et al. It was discussed by the authors that the sorption on the adsorbent surface was because of speciation of the metal ions and the surface charge of the adsorbent [61]. In the work reported by $\mathrm{He}$ et al. iron impregnated biochar was used for the adsorption of arsenic from wastewater. The modified adsorbent exhibited improved properties like greater surface area, better porous structure, and larger oxygen containing groups which are beneficial for adsorption process [63].

Zhu et al. explored the capability of fluorhydroxyapatite composites for removing cadmium from wastewater. The adsorption was found to be because of ion-exchange process between the adsorbent and the adsorbate [65].

In the adsorption of chromium from wastewater trioctylamine treated graphene oxide was used as efficient adsorbent. The interaction between the protonated amine and the chromate anion was contributing towards the adsorption [66].

\section{Conclusion}

The current work explored the feasibility of the impregnation process for improving the property and the adsorption capacity of the adsorbent. The study reviewed the advantages and disadvantages of porous materials as adsorbent for wastewater treatment. The adsorbent surface can be modified by subjecting to various treatment methods. It also investigates the features and significance of different treatment methods. It discusses the various precursor materials used for adsorbent preparation, the impregnating agent, the pollutant removed, the experimental operating conditions and the adsorption capacity. Thus it can be inferred that through the process of impregnation, the type of impregnating agent used the adsorption capacity increases. Therefore selecting the precursor material and the impregnating agent is important in making the adsorbent more efficient and the wastewater treatment process economical.

\section{References}

[1] H. Ali, 'Biodegradation of synthetic dyes - a review', Water, Air, \& Soil Pollution, 213(1-4) (2010) 251-273.

[2] U.M. Nagpal, A.V. Bankar, N.J. Pawar, B.P. Kapadnis, S.S. Zinjarde, 'Equilibrium and kinetic studies on biosorption of heavy metals by leaf powder of paper mulberry (Broussonetia papyrifera)', Water, Air, \& Soil Pollution, 215(1-4) (2011) 177-188.

[3] A.M.A. Al-Haidary, F.H. Zanganah, S.R. Al-Azawi, F.I. Khalili, A.H Al-Dujaili, 'A study on using date palm fibers and leaf base of palm as adsorbents for $\mathrm{Pb}$ (II) ions from its aqueous solution', Water, Air, \& Soil Pollution, 214(1-4) (2011) 73-82.

[4] E. Deliyanni, T.J. Bandosz, K.A. Matis, 'Impregnation of activated carbon by iron oxyhydroxide and its effect on arsenate removal', Journal of Chemical Technology \& Biotechnology, 88(6) (2013) 1058-1066.
[5] J.J. Park, S.Y. Jung, C.G. Park, S.C. Lee, J.N. Kim, J.C. Kim, 'The removal of the acetonitrile using activated carbon-based sorbent impregnated with sodium carbonate', Korean Journal of Chemical Engineering, 29(4) (2012) 489-493.

[6] F.A. Banat, S. Al-Asheh, 'Biosorption of phenol by chicken feathers', Environmental Engineering and Policy, 2(2) (2000) 85-90.

[7] M. Owlad, M.K. Aroua, W.M.A.W. Daud, 'Hexavalent chromium adsorption on impregnated palm shell activated carbon with polyethyleneimine', Bioresource Technology, 101(14) (2010) 5098-5103.

[8] C.K. Ahn, D. Park, S.H. Woo, J.M. Park, 'Removal of cationic heavy metal from aqueous solution by activated carbon impregnated with anionic surfactants', Journal of hazardous materials, 164(2-3) (2009) 11301136.

[9] X.D. Sun, W.G. Lin, L.J. Wang, B. Zhou, X.L. Lv, Y. Wang, S.J. Zheng W.M. Wang, Y.G. Tong, J.H. Zhu, 'Liquid adsorption of tobacco specific N-nitrosamines by zeolite and activated carbon', Microporous and mesoporous materials, 200 (2014) 260-268.

[10] S. Jain, A. Bansiwal, R.B. Biniwale, S. Milmille, S. Das, S. Tiwari, P.S. Antony, 'Enhancing adsorption of nitrate using metal impregnated alumina', Journal of Environmental Chemical Engineering, 3(4) (2015) 2342-2349.

[11] J.H. Park, J.J. Wang, R. Xiao, N. Tafti, R.D. DeLaune, D.C. Seo, 'Degradation of Orange $\mathrm{G}$ by Fenton-like reaction with $\mathrm{Fe}$-impregnated biochar catalyst', Bioresource technology, 249 (2018) 368-376.

[12] H. Jung, S. Jeon, D.H. Jo, J. Huh, S.H. Kim, 'Effect of crosslinking on the $\mathrm{CO} 2$ adsorption of polyethyleneimine-impregnated sorbents', Chemical Engineering Journal, 307 (2017) 836-844.

[13] M.A. Lira, R. Navarro, I. Saucedo, M. Martinez, E. Guibal, 'Influence of the textural characteristics of the support on $\mathrm{Au}$ (III) sorption from $\mathrm{HCl}$ solutions using Cyphos IL101-impregnated Amberlite resins', Chemical Engineering Journal, 302 (2016) 426-436.

[14] S. Ahluwalia, N.T. Prakash, R. Prakash, B. Pal, 'Improved degradation of methyl orange dye using bio-co-catalyst Se nanoparticles impregnated $\mathrm{ZnS}$ photocatalyst under UV irradiation', Chemical Engineering Journal, 306 (2016) 1041-1048.

[15] S. Ahmed, A. Ramli, S. Yusup, 'Development of polyethyleniminefunctionalized mesoporous Si-MCM-41 for CO2 adsorption', Fuel Processing Technology, 167 (2017) 622-630

[16] L. Singh, P. Rekha, S. Chand, 'Cu-impregnated zeolite Y as highly active and stable heterogeneous Fenton-like catalyst for degradation of Congo red dye', Separation and Purification Technology, 170 (2016) 321-336.

[17] J. Zhang, Q. Shi, C. Zhang, J. Xu, B. Zhai, B. Zhang, 'Adsorption of Neutral Red onto Mn-impregnated activated carbons prepared from Typha orientalis', Bioresource technology, 99(18) (2008) 8974-8980.

[18] C. Han, H. Liu, H. Chen, L. Zhang, G. Wan, X. Shan, J. Deng, Y. Luo, 'Adsorption performance and mechanism of As (V) uptake over mesoporous Y-Al binary oxide', Journal of the Taiwan Institute of Chemical Engineers, 65 (2016) 204-211.

[19] O.A. Al-Hartomy, A.A. Al-Ghamdi, S.A.F. Al Said, N.T. Dishovsky, P.A. Malinova, R.N. Nikolov, R.N., Effect of carbon-silica dual phase filler obtained by impregnation method on the properties of SBR-based composites', Proceedings of the Institution of Mechanical Engineers, Part L: Journal of Materials: Design and Applications, 230(1) (2016) 116-120.

[20] A.A. Al-Ghamdi, O.A. Al-Hartomy, F.R. Al-Solamy, N. Dishovsky, P. Malinova, L. Lakov, Characterization of hybrid fillers based on carbon black of different types obtained by impregnation', Proceedings of the Institution of Mechanical Engineers, Part L: Journal of Materials: Design and Applications, 231(7) (2017) 584-599.

[21] H. Yu, T. Wang, L. Yu, W. Dai, N. Ma, X. Hu, Y. Wang, 'Remarkable adsorption capacity of $\mathrm{Ni}$-doped magnolia-leaf-derived bioadsorbent for Congo red', Journal of the Taiwan Institute of Chemical Engineers, 64 (2016) 279-284.

[22] B. Agarwal, C. Balomajumder, 'Removal of phenol and cyanide in multi-substrate system using copper impregnated activated carbon (Cu-GAC)', Environmental Progress \& Sustainable Energy, 34(6) (2015) 1714-1723.

[23] A.K. Hammed, N. Dewayanto, D. Du, M.H. Ab Rahim, M.R. Nordin, 'Novel modified ZSM-5 as an efficient adsorbent for methylene blue removal', Journal of Environmental Chemical Engineering, 4(3) (2016) 2607-2616.

[24] G. Jin, Y. Eom, T.G. Lee, 'Removal of $\mathrm{Hg}$ (II) from aquatic environments using activated carbon impregnated with humic acid', Journal of Industrial and Engineering Chemistry, 42 (2016) 46-52.

[25] J. Deng, Y. Liu, S. Liu, G. Zeng, X. Tan, B. Huang, X. Tang, S. Wang, Q. Hua, Z. Yan, 'Competitive adsorption of $\mathrm{Pb}$ (II), $\mathrm{Cd}$ (II) and $\mathrm{Cu}$ (II) onto chitosan-pyromellitic dianhydride modified biochar', Journal of colloid and interface science, 506 (2017) 355-364.

[26] K. Wang, J. Zhao, H. Li, X. Zhang, H. Shi, 'Removal of cadmium ( II ) from aqueous solution by granular activated carbon supported magnesi- 
um hydroxide', Journal of the Taiwan Institute of Chemical Engineers, 61 (2016) 287-291.

[27] A. Behnamfard, M.M. Salarirad, F. Vegliò, 'Removal of Zn (II) ions from aqueous solutions by ethyl xanthate impregnated activated carbons', Hydrometallurgy, 144 (2014) 39-53.

[28] B. Cao, W. Shen, Y. Liu, 'Adsorption desulphurization of gasoline by silver loaded onto modified activated carbons' Adsorption Science \& Technology, 26(4) (2008) 225-231.

[29] R. Xie, W. Jiang, L. Wang, J. Peng, Y. Chen, 'Effect of pyrolusite loading on sewage sludge-based activated carbon in $\mathrm{Cu}$ (II), $\mathrm{Pb}$ (II), and $\mathrm{Cd}$ (II) adsorption', Environmental Progress \& Sustainable Energy, 32(4) (2013) 1066-1073.

[30] M. Anbia, S. Amirmahmoodi, 'Removal of $\mathrm{Hg}$ (II) and Mn (II) from aqueous solution using nanoporous carbon impregnated with surfactants', Arabian Journal of Chemistry, 9 (2016) S319-S325.

[31] V. Gaur, A. Sharma, N. Verma, 'Removal of $\mathrm{SO}_{2}$ by activated carbon fibre impregnated with transition metals', The Canadian Journal of Chemical Engineering, 85(2) (2007) 188-198.

[32] P. Rule, K. Balasubramanian, R.R. Gonte, 'Uranium (VI) remediation from aqueous environment using impregnated cellulose beads', Journal of environmental radioactivity, 136 (2014) 22-29.

[33] A. Kongnoo, P. Intharapat, P. Worathanakul, C. Phalakornkule, 'Diethanolamine impregnated palm shell activated carbon for $\mathrm{CO}_{2}$ adsorption at elevated temperatures', Journal of Environmental Chemical Engineering, 4(1) (2016) 73-81.

[34] M. Wang, G. Li, L. Huang, J. Xue, Q. Liu, N. Bao, J. Huang, 'Study of ciprofloxacin adsorption and regeneration of activated carbon prepared from Enteromorpha prolifera impregnated with $\mathrm{H}_{3} \mathrm{PO}_{4}$ and sodium benzenesulfonate', Ecotoxicology and environmental safety, 139 (2017) 3642.

[35] B.R. Vieira, A.M. Pintor, R.A. Boaventura, C.M. Botelho, S.C. Santos, 'Arsenic removal from water using iron-coated seaweeds', Journal of environmental management, 192 (2017) 224-233.

[36] M. Sharma, S. Hazra, S. Basu, 'Kinetic and isotherm studies on adsorption of toxic pollutants using porous $\mathrm{ZnO} @ \mathrm{SiO}_{2}$ monolith', Journal of colloid and interface science, 504 (2017) 669-679.

[37] F. Liu, S. Chen, Y. Gao, 'Synthesis of porous polymer based solid amine adsorbent: effect of pore size and amine loading on $\mathrm{CO}_{2}$ adsorption', Journal of colloid and interface science, 506 (2017) 236-244.

[38] K. Wu, T. Liu, C. Lei, F. Zhang, 'Evaluation of Al-based nanoparticle-impregnated sawdust as an adsorbent from byproduct for the removal of arsenic (V) from aqueous solutions', Environmental Progress \& Sustainable Energy, 36(5) (2017) 1314-1322.

[39] Y. Zhu, H. Zhang, H. Zeng, M. Liang, R. Lu, 'Adsorption of chromium (VI) from aqueous solution by the iron (III)-impregnated sorbent prepared from sugarcane bagasse', International Journal of Environmental Science and Technology, 9(3) (2012) 463-472.

[40] J. K. Yang, H. J. Park, H.D. Lee, S.M. Lee, 'Removal of Cu (II) by activated carbon impregnated with iron (III)', Colloids and Surfaces A Physicochemical and Engineering Aspects, 337(1-3) (2009) 154-158.

[41] X.P. Liao, W. Tang, R.Q. Zhou, B. Shi, 'Adsorption of metal anions of vanadium (V) and chromium (VI) on $\mathrm{Zr}$ (IV)-impregnated collagen fiber', Adsorption, 14(1) (2008) 55-64.

[42] L. Zhang, T. Zhu, X. Liu, W. Zhang, 'Simultaneous oxidation and adsorption of As (III) from water by cerium modified chitosan ultrafine nanobiosorbent', Journal of hazardous materials, 308 (2016) 1-10.

[43] P. Lodeiro, S.M. Kwan, J.T. Perez, L.F. González, C. Gerente, Y. Andres, G. McKay, 'Novel Fe loaded activated carbons with tailored properties for As (V) removal: Adsorption study correlated with carbon surface chemistry', Chemical engineering journal, 215 (2013)105-112.

[44] M. Ciopec, C.M. Davidescu, A. Negrea, C. Muntean, A. Popa, P. Negrea, L. Lupa, 'Equilibrium and kinetic studies of the adsorption of $\mathrm{Cr}$ (III) ions onto Amberlite XAD-8 impregnated with Di-(2-ethylhexyl) Phosphoric Acid (DEHPA)', Adsorption Science \& Technology, 29(10) (2011) 989-1005

[45] Y. Wang, X. Wang, X. Wang, M. Liu, Z. Wu, L. Yang, S. Xia, J. Zhao, 'Adsorption of $\mathrm{Pb}$ (II) from aqueous solution to Ni-doped bamboo charcoal', Journal of Industrial and Engineering Chemistry, 19(1) (2013) 353-359.

[46] H. Liu, S. Feng, N. Zhang, X. Du, Y. Liu, 'Removal of $\mathrm{Cu}$ (II) ions from aqueous solution by activated carbon impregnated with humic acid', Frontiers of Environmental Science \& Engineering, 8(3) (2014) 329-336.

[47] G. Li, J. Lan, J. Liu, G. Jiang, 'Synergistic adsorption of As (V) from aqueous solution onto mesoporous silica decorated orderly with $\mathrm{Al}_{2} \mathrm{O}$ and $\mathrm{Fe}_{2} \mathrm{O}_{3}$ nanoparticles', Journal of colloid and interface science, 405 (2013) 164-170.

[48] M. Fazlzadeh, R. Khosravi, A. Zarei, 'Green synthesis of zinc oxide nanoparticles using Peganum harmala seed extract, and loaded on Peganum harmala seed powdered activated carbon as new adsorbent for removal of Cr (VI) from aqueous solution', Ecological Engineering, 103 (2017) 180-190.
[49] J.S. Kim, J. Yi, 'Selective removal of copper ions from aqueous solutions using modified silica beads impregnated with LIX 84', Journal of Chemical Technology \& Biotechnology: International Research in Process, Environmental \& Clean Technology, 74(6) (1999) 544-550.

[50] S. Mandal, S.S. Mahapatra, R.K. Patel, 'Enhanced removal of Cr (VI) by cerium oxide polyaniline composite: optimization and modeling approach using response surface methodology and artificial neural networks', Journal of Environmental Chemical Engineering, 3(2) (2015) 870-885.

[51] S.A. Abo-El-Enein, M.A. Eissa, A.A. Diafullah, M.A. Rizk, F.M. Mohamed, 'Removal of some heavy metals ions from wastewater by copolymer of iron and aluminum impregnated with active silica derived from rice husk ash', Journal of hazardous materials, 172(2-3) (2009) 574-579.

[52] M. Salim, J.N. Bhakta, N. Maneesh, Y. Munekage, K. Motomura, 'Magnesium oxide-impregnated tuff soil-derived ceramic: a novel cadmium (II) adsorbing media', Applied Water Science, 7(4) (2017) 1625 1633.

[53] Y. Yurekli, 'Removal of heavy metals in wastewater by using zeolite nano-particles impregnated polysulfone membranes', Journal of hazardous materials, 309 (2016) 53-64.

[54] L. Hao, T. Zheng, J. Jiang, G. Zhang, P. Wang, 'Removal of As (III) and As (V) from water using iron doped amino functionalized sawdust: characterization, adsorptive performance and UF membrane separation', Chemical Engineering Journal, 292 (2016) 163-173.

[55] J. Wang, W. Xu, L. Chen, X. Huang, J. Liu, 'Preparation and evaluation of magnetic nanoparticles impregnated chitosan beads for arsenic removal from water', Chemical Engineering Journal, 251 (2014) 25-34.

[56] T. Wajima, K. Sugawara, 'Adsorption behaviors of mercury from aqueous solution using sulfur-impregnated adsorbent developed from coal', Fuel processing technology, 92(7) (2011) 1322-1327.

[57] P. Panneerselvam, N. Morad, K.A. Tan, 'Magnetic nanoparticle $\left(\mathrm{Fe}_{3} \mathrm{O}_{4}\right)$ impregnated onto tea waste for the removal of nickel (II) from aqueous solution', Journal of hazardous materials, 186(1) (2011) 160-168.

[58] A.V. Vitela-Rodriguez, J.R. Rangel-Mendez, 'Arsenic removal by modified activated carbons with iron hydro (oxide) nanoparticles', Journal of environmental management, 114 (2013) 225-231.

[59] N. Chaudhary, C. Balomajumder, 'Optimization study of adsorption parameters for removal of phenol on aluminum impregnated fly ash using response surface methodology', Journal of the Taiwan Institute of Chemical Engineers, 45(3) (2014) 852-859.

[60] H. Peng, P. Gao, G. Chu, B. Pan, J. Peng, B. Xing, 'Enhanced adsorption of $\mathrm{Cu}$ (II) and $\mathrm{Cd}$ (II) by phosphoric acid-modified biochars', Environmental Pollution, 229 (2017) 846-853.

[61] Z. Zhou, Y.G. Liu, S.B. Liu, H.Y. Liu, G.M. Zeng, X.F. Tan, C.P. Yang, Y. Ding, Z.L. Yan, X.X. Cai, 'Sorption performance and mechanisms of arsenic (V) removal by magnetic gelatin-modified biochar', Chemical Engineering Journal, 314 (2017) 223-231.

[62] Y. Zhang, J. Fan, M. Fu, Y.S. Ok, Y. Hou, C. Cai, 'Adsorption antagonism and synergy of arsenate (V) and cadmium (II) onto Fe-modified rice straw biochars', Environmental geochemistry and health (2017) 112.

[63] R. He, Z. Peng, H. Lyu, H. Huang, Q. Nan, J. Tang, 'Synthesis and characterization of an iron-impregnated biochar for aqueous arsenic removal', Science of the Total Environment, 612 (2018) 1177-1186.

[64] B. Kakavandi, A. Jonidi Jafari, R. Rezaei Kalantary, S. Nasseri, A. Esrafili, A. Gholizadeh, A. Azari, 'Simultaneous adsorption of lead and aniline onto magnetically recoverable carbon: Optimization, modeling and mechanism', Journal of Chemical Technology \& Biotechnology, 91(12) (2016) 3000-3010

[65] X.H. Zhu, J. Li, J.H. Luo, Y. Jin, D. Zheng, 'Removal of cadmium (II) from aqueous solution by a new adsorbent of fluor-hydroxyapatite composites', Journal of the Taiwan Institute of Chemical Engineers, 70 (2017) 200-208

[66] A.S.K. Kumar, S.S. Kakan, N. Rajesh, 'A novel amine impregnated graphene oxide adsorbent for the removal of hexavalent chromium', Chemical engineering journal, 230 (2013) 328-337.

[67] A. Sigdel, J. Park, H. Kwak, P.K. Park, 'Arsenic removal from aqueous solutions by adsorption onto hydrous iron oxide-impregnated alginate beads', Journal of industrial and engineering chemistry, 35 (2016) 277 286.

[68] R. Kumar, S.J. Kim, K.H. Kim, S.H. Lee, H.S. Park, B.H. Jeon, 'Removal of hazardous hexavalent chromium from aqueous phase using zirconium oxide-immobilized alginate beads', Applied Geochemistry, 88 (2018) 113-121.

[69] S. Wan, J. Wu, S. Zhou, R. Wang, B. Gao, F. He, 'Enhanced lead and cadmium removal using biochar-supported hydrated manganese oxide (HMO) nanoparticles: Behavior and mechanism', Science of The Total Environment, 616 (2018) 1298-1306.

[70] N. Zhu, T. Yan, J. Qiao, H. Cao, 'Adsorption of arsenic, phosphorus and chromium by bismuth impregnated biochar: Adsorption mechanism and depleted adsorbent utilization', Chemosphere, 164 (2016) 32-40. 